\title{
YERSINIA RUCKERI SEPTICAEMIA IN EXPERIMENTALLY INFECTED CARP (CYPRINUS CARPIO L.) FINGERLINGS
}

\author{
Anera BERC $^{1^{*}}$, Z. PETRINEC $^{1}$, Željka MATAŠIN $^{1}$ and Z. KOZARIĆ ${ }^{2}$ \\ ${ }^{1}$ Department for Biology and Pathology of Fish and Bees; ${ }^{2}$ Department of Anatomy, \\ Histology and Embryology, University of Zagreb, Veterinary Faculty, Heinzelova 55, \\ 10000 Zagreb, Croatia
}

(Received May 19, 1998; accepted September 2, 1998)

The presence of Yersinia ruckeri, the causal agent of enteric redmouth disease (ERM) in salmonids and a few other freshwater fish, has so far been reported from a variety of sources including the intestine of healthy carp. Since there are no data on the pathogenicity of this bacterium for carp, 15 fingerlings were experimentally infected by intraperitoneal injection of about $5 \times 10^{5}$ cells. Thirteen injected fish were moribund or died within 4 days with septicaemic lesions. Two survivors were sampled on Day 28 after infection. Yersinia ruckeri was reisolated from the internal organs of all experimental fish. By histopathological examination moribund fish had generalised bacteriaemia with inflammation, degeneration and necrotic foci in kidney, liver and spleen, corresponding to findings described previously in ERM of rainbow trout. Survivors of challenge on Day 28 had a chronic disease characterised by prominent peritonitis and enteritis, exhaustion of the erythroid, granuloid and lymphoid components in haematopoietic kidney tissue as well as focal degeneration and necrosis in organs. These data indicate a high sensitivity of carp to intraperitoneal infection with a relatively low dose of Y. ruckeri.

Key words: Yersinia ruckeri, enteric redmouth disease (ERM), common carp (Cyprinus carpio), histopathology

Yersinia ruckeri is the causal agent of the acute to chronic enteric redmouth disease (ERM) or yersiniosis of salmonid fish. The disease and the organism were first described in the United States (Ross et al., 1966; Rucker, 1966) and thereafter in several European countries and Australia (Austin and Austin, 1987). In Croatia, Oraić (1993) reported ERM in rainbow trout (Oncorhynchus mykiss) caused by serovar I.

Although $Y$. ruckeri most commonly affects the rainbow trout, its host range probably includes all salmonids (McDaniel, 1979). It was also isolated from seven diseased and six apparently healthy non-salmonid species, a human

*E-mail: aberc@vef.hr; Fax: 003851214697 
clinical specimen and a variety of other sources, including river water (data from Stevenson et al., 1993). The bacterium can survive starvation in freshwater for at least 4 months (Thorsen et al., 1992). Isolation from healthy common carp (Cyprinus carpio L.) was reported by Fuhrmann et al. (1984), Schlotfeldt et al. (1985), Austin and Austin (1987) and Enriquez and Zamora (1987), but there are no data as to whether the bacterium can cause disease in this species. We tested the sensitivity of carp to intraperitoneal infection with $Y$. ruckeri and registered its high susceptibility.

\section{Materials and methods}

Yersinia ruckeri for inoculation of carp belonged to serovar I (reference isolate RD-16 was kindly provided by R. L. Davies). It was inoculated onto tryptose soy agar (TSA, Oxoid) and incubated at $22{ }^{\circ} \mathrm{C}$ for $48 \mathrm{~h}$. Colonies were washed off with sterile $0.65 \% \mathrm{NaCl}$ solution (further on: SS), suspended by mixing and sedimented by centrifugation. The sediment was resuspended in SS and serial tenfold dilutions in SS were prepared for determination of bacterial cell concentration using McFarland's turbidimetric method. Carp were inoculated intraperitoneally with about $5 \times 10^{5}$ cells in $0.1 \mathrm{ml}$ of SS.

Carp for the experiment were brought to the laboratory from a fish farm free of major diseases. Before the experiment, five of them were dissected and examined by bacteriological and virological methods. After seven days, 30 carp of about $15 \mathrm{~g}$ (approx. $85 \mathrm{~mm}$ ) were randomly divided into two groups. Each fish in Group 1 was inoculated with Y. ruckeri suspension. Carp in Group 2 were injected with $0.1 \mathrm{ml}$ of SS. Groups were placed into two glass aquaria (100 litres) provided with a constant slow flow of dechlorinated tap water $\left(14-18{ }^{\circ} \mathrm{C}\right)$ and aeration. The experiment lasted for 28 days.

\section{Sampling}

Moribund carp as well as survivors in Groups 1 and 2 on Day 28 were anaesthetised with MS-222 and bled by cutting the gill arches. All fish were examined for external lesions and by dissection. The parenchymatous organs of all fish were sampled for bacteriological and virological examination and those of moribund ones and of survivors from both groups also for histology.

\section{Bacteriological examination}

Materials from kidneys and liver were inoculated onto TSA plates and incubated for $48 \mathrm{~h}$ at $22{ }^{\circ} \mathrm{C}$. The latter temperature was used for incubation of all subsequent inoculations of media and tests. Selected colonies were subcultured on TSA plates. The 24-h growth was used for preparation of Gram-stained smears, 
inoculation of Shott-Waltman's agar (further on: Sw) (Waltman et al., 1984), and of tryptone soy broth for determination of motility. Media for conventional biochemical tests, including the test for oxidation or fermentation of glucose (Hugh and Leifson, 1953), were inoculated with 48-h-old growth on TSA subculture. Motility was determined by the "hanging drop" method after $24 \mathrm{~h}$. Other results were recorded after 48 or $72 \mathrm{~h}$ except for the methyl red and Voges-Proskauer (VP) reactions which were read 5 days after incubation. The production of diffusible pigments was determined according to King et al. (1954). Isolates were identified according to Krieg and Holt (1984) as well as Amos (1985).

\section{Virological examination}

Kidney, spleen and liver samples were examined for presence of virus by inoculation of EPC cells (Fijan et al., 1983) and by standard isolation technique at $20^{\circ} \mathrm{C}$.

\section{Histological examination}

Samples of the heart, kidney, spleen, liver and intestine were fixed in $10 \%$ buffered formalin and embedded in paraffin. Sections were stained with haematoxylin and eosin (Romeis, 1968) and examined by light microscopy.

\section{Results}

Control carp (Group B) had no clinical or pathoanatomical signs of disease. All of them were alive on Day 28. The results of bacteriological and virological examinations were negative. The organs were histologically normal.

The course of mortality and results of bacteriological examination of carp in Group 1 are presented in Table 1. Virological examinations were negative. On Day 2 the dead and moribund carp had exophthalmos, dark skin coloration, petechial bleeding and suffusion on the gill arches, belly, bases of pectoral and pelvic fins, operculi, lateral line area and at the injection site. The gills were pale. All internal organs were oedematous. Petechial bleeding was pronounced in the liver. The peritoneal cavity contained a small amount of a pale red and slightly turbid fluid. On Days 3 and 4 the dead and moribund carp had the same symptoms. One of them had petechial bleeding in the oral cavity.

On Day 28, two survivors in Group 1 had pale gills and a yellow fluid in the second half of the intestine.

Gram- and cytochrome oxidase negative, motile rods were isolated from the organs of all fish in Group 1. They were found in pure culture in 14 fish. This isolate inoculated onto SW agar showed a green colony with a zone of hydrolysis. A second, cytochrome oxidase positive, Gram-negative rod was iso- 
lated from one carp which died on day 3. After inoculation onto two King's selective plates it was tentatively identified as Pseudomonas sp. The basic biochemical characteristics of the isolates are presented in Table 2.

\section{Table 1}

Mortality and results of bacteriological examination of carp infected experimentally with Yersinia ruckeri (Group 1)

\begin{tabular}{rcll}
\hline Day & $\begin{array}{c}\text { Dead + moribund } \\
\text { sampled carp }\end{array}$ & Survivors (\%) & \multicolumn{1}{c}{ Bacteriological findings } \\
\hline 2 & $5+3$ & $7(53.33)$ & Y. muckeri \\
3 & $1+2$ & $4(20.00)$ & Y. ruckeri $(+$ P. fluorescens in 1 fish) \\
4 & +2 & $2(13.33)$ & Y. ruckeri \\
28 & $2(13.33)$ & Y. ruckeri \\
\hline
\end{tabular}

Table 2

Some characteristics of Yersinia ruckeri and of Pseudomonas sp. isolated from carp injected with Y. ruckeri strain RD-16

\begin{tabular}{lcc}
\hline \multirow{2}{*}{ Characteristic } & \multicolumn{2}{c}{ Reaction $^{*}$} \\
\cline { 2 - 3 } & Y. ruckeri & Pseudomonas sp. \\
\hline Gram & - & - \\
Motility at $22^{\circ} \mathrm{C}$ & + & + \\
Oxidase & - & + \\
Indole & - & - \\
Urease & - & - \\
O/F test & + & - \\
Catalase & + & + \\
Voges-Proskauer & - & - \\
Methyl red & + & + \\
Simmons citrate & + & + \\
Gelatinase & + & + \\
Fermentation of: & & - \\
Glucose & + & + \\
Sucrose & - & - \\
SW agar & + & \\
King A & $/$ & \\
King B & & \\
\hline
\end{tabular}

${ }^{*}+=$ positive $;-=$ negative; $/=$ strain was not inoculated onto this medium

Histological examination of five moribund fish collected near the water surface on Days 2 and 3 revealed oedema, degeneration, necrosis and perivas- 
cular bleeding in all organs. The necrotic gut epithelium was sloughed off and the submucosa was inflamed. Peritonitis with phagocytosis of bacterial cells was also pronounced. Clumps of bacteria were found in kidneys, liver and spleen. The adventitia of blood vessels contained groups of phagocytic cells surrounded by rodlet cells. Two moribund fish collected on Day 4 exhibited the same type of lesions and peritonitis.

The ventricular muscle of two carp from Group 1 sampled on Day 28 had groups of rodlet cells and leukocyte accumulation, a few foci of degeneration (Figs 1 and 2) and areas with pigment cells (Fig. 2).

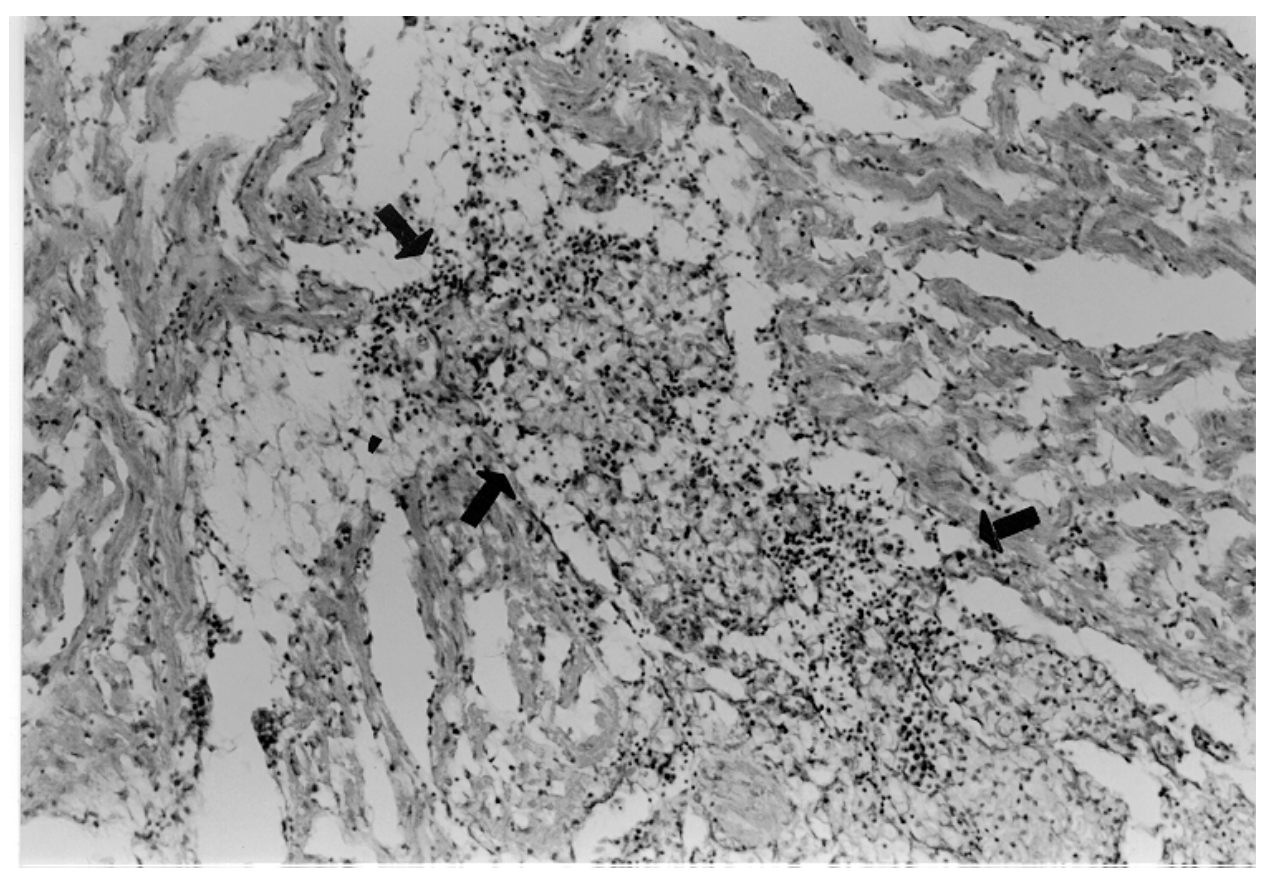

Fig. 1. Accumulation of rodlet cells and leukocytes (delineated by 3 arrows) and myodegeneration in carp with chronic yersiniosis, sampled on Day 28 after intraperitoneal injection of Yersinia ruckeri. Haematoxylin and eosin $(\mathrm{HE}), \times 174$

Local foci of chronic pericarditis were also present. The liver serosa was thickened due to chronic peritonitis and the underlying parenchymatous tissue layer was infiltrated, degenerated and occasionally necrotic (Fig. 3). The epithelium of the bile ducts was degenerated or necrotic and often sloughed off (Fig. 4). The pancreatic tissue was normal. The peritoneum covering the lobes of trunk kidney was rather thick and contained capillaries and pigment cells (Fig. 5). Some of the tubules had degenerated and necrotic cells (Figs 5 and 5a). 


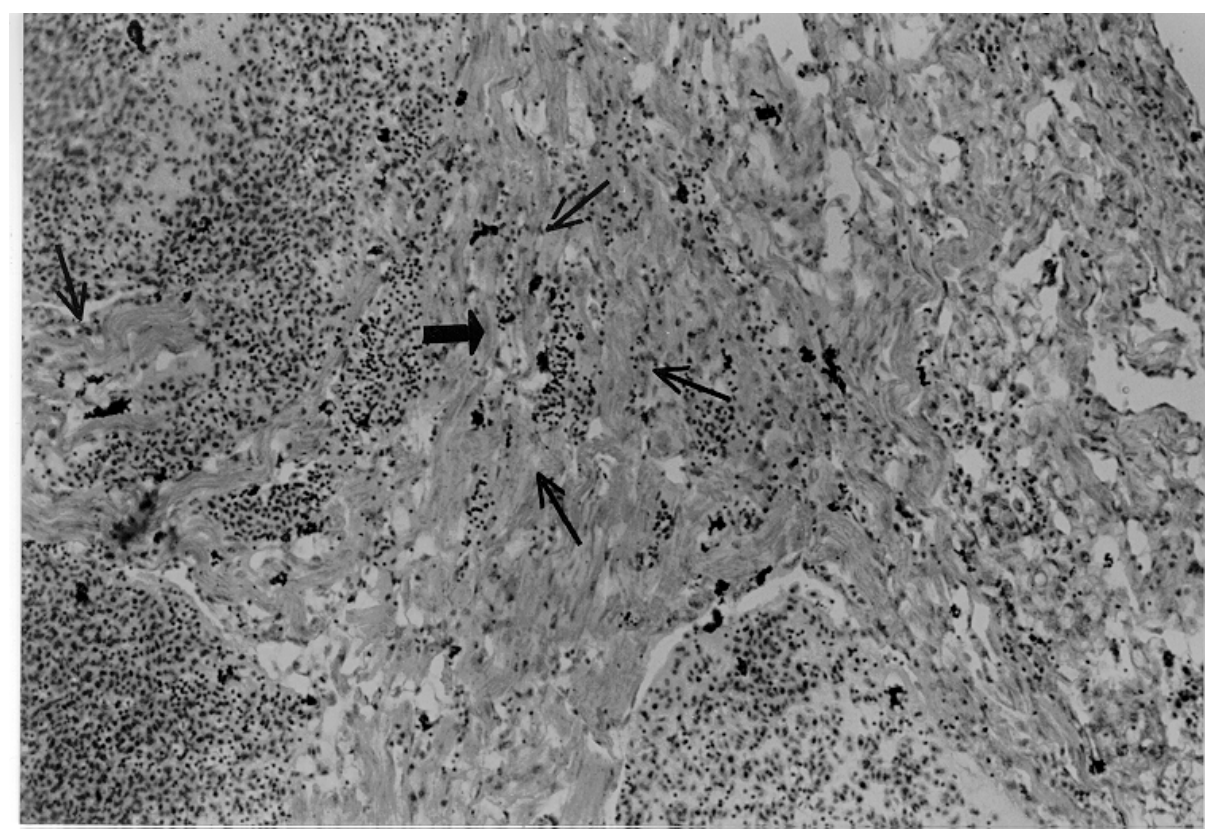

Fig. 2. Widened capillaries, pigment cells (arrow) and occasional myodegeneration in chronic yersiniosis. HE, $\times 166$

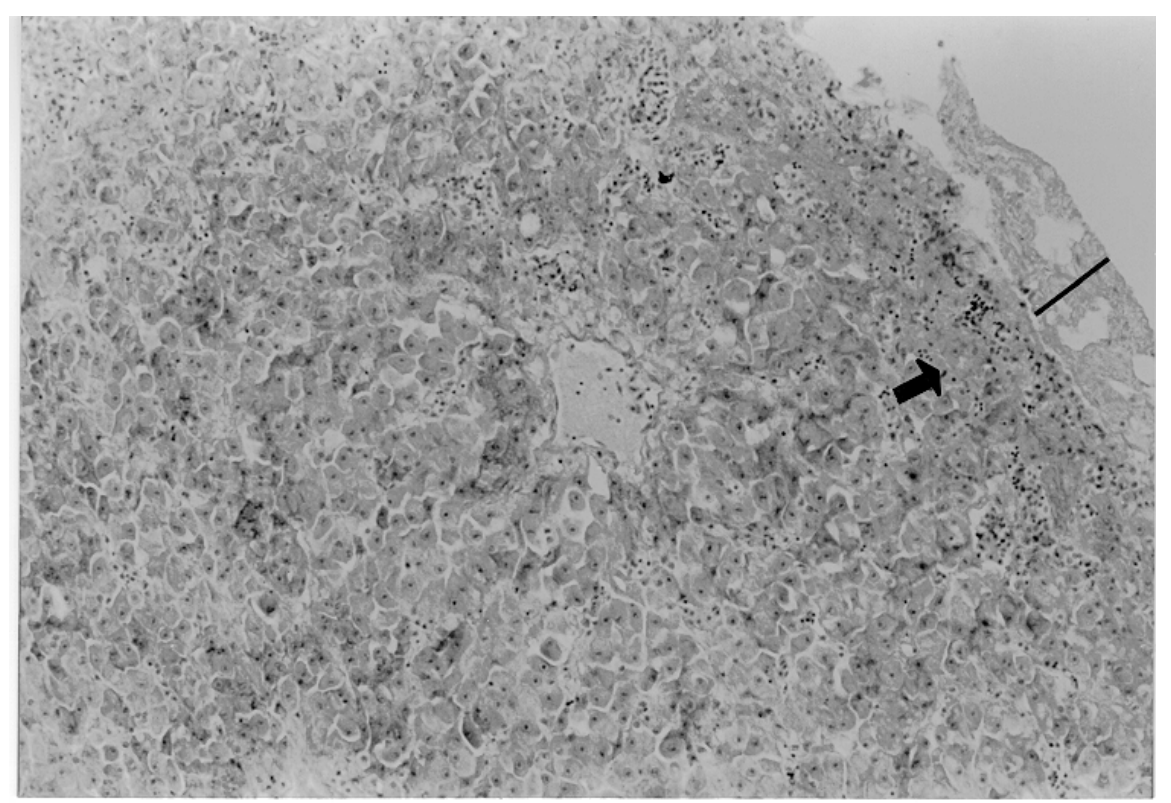

Fig. 3. Widened serosa (bar), with degeneration, subserosal necrosis and infiltration (arrow) in the liver. HE, $\times 160$ 


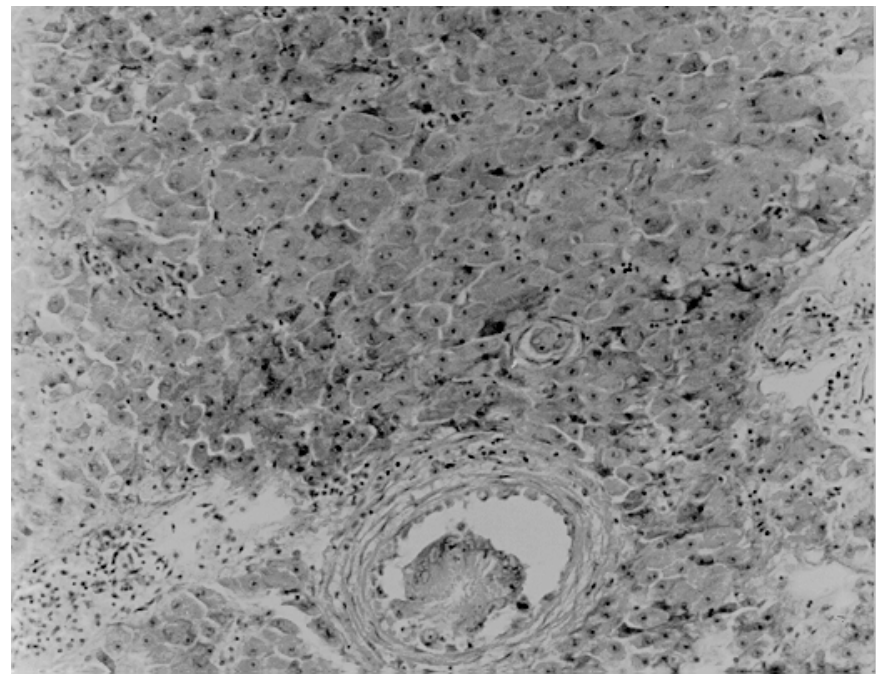

Fig. 4. Partial desquamation of epithelium in large and small bile ducts in chronic yersiniosis. $\mathrm{HE}, \times 175$

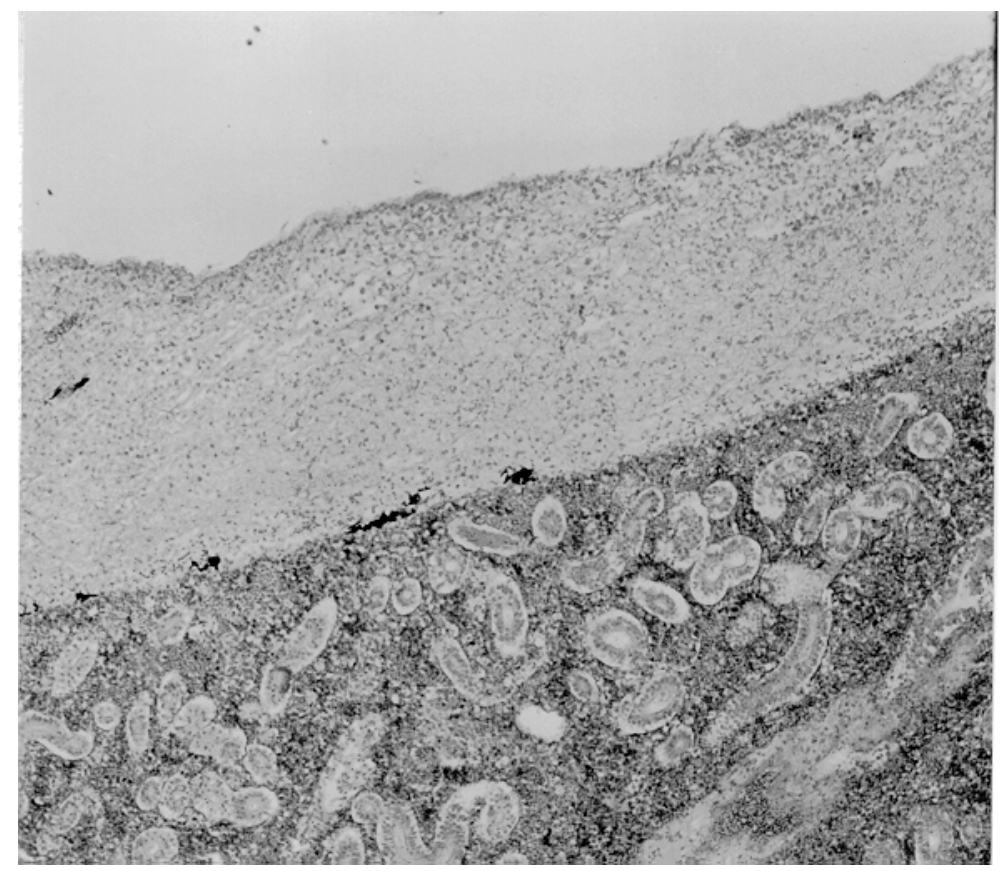

Fig. 5. Enormously widened serosa with vascularization and pigment cells on the surface of the kidney lobe in chronic yersiniosis. HE, $\times 90$ 


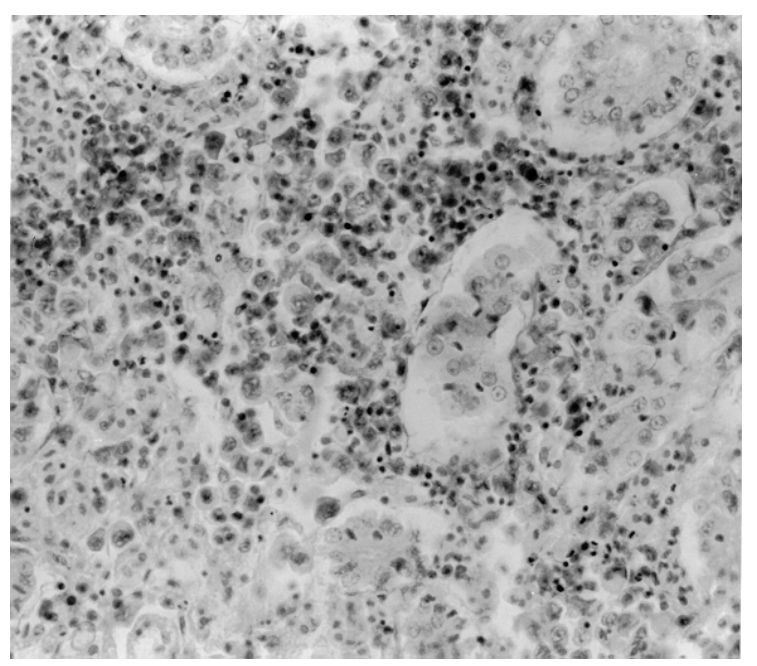

Fig. 5a. Necrotic tubules in kidneys and depletion of lymphoid, erythroid and granuloid cells in chronic yersiniosis. $\mathrm{HE}, \times 265$

The walls of some blood vessels were widened. The haematopoietic tissue consisted mainly of large mononuclear cells with a lack of normal amount of lymphoid, erythroid and granuloid cells (Fig. 5a). The serosa covering the spleen and the underlying tissue were mostly intact but the part exposed to the parietal peritoneum (not covered by liver or intestine) was slightly thickened and a narrow subserous zone was necrotic (Fig. 6).

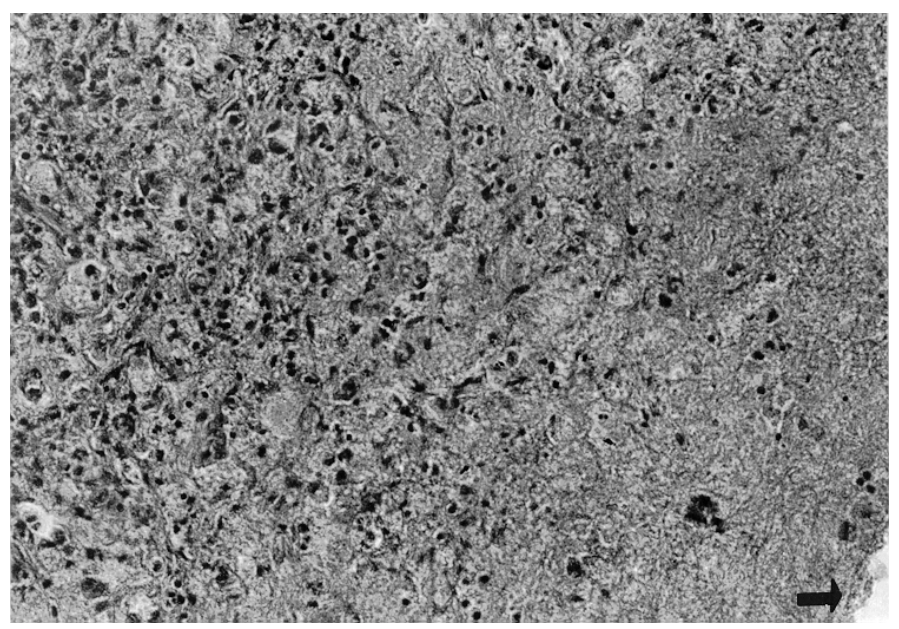

Fig. 6. Necrotic subserous zone in spleen on the part exposed to the parietal peritoneum (arrow). $\mathrm{HE}, \times 124$ 
The intestinal epithelium of the hindgut was degenerated, necrotic and sloughed off, and the submucosa was inflamed (Fig. 7).

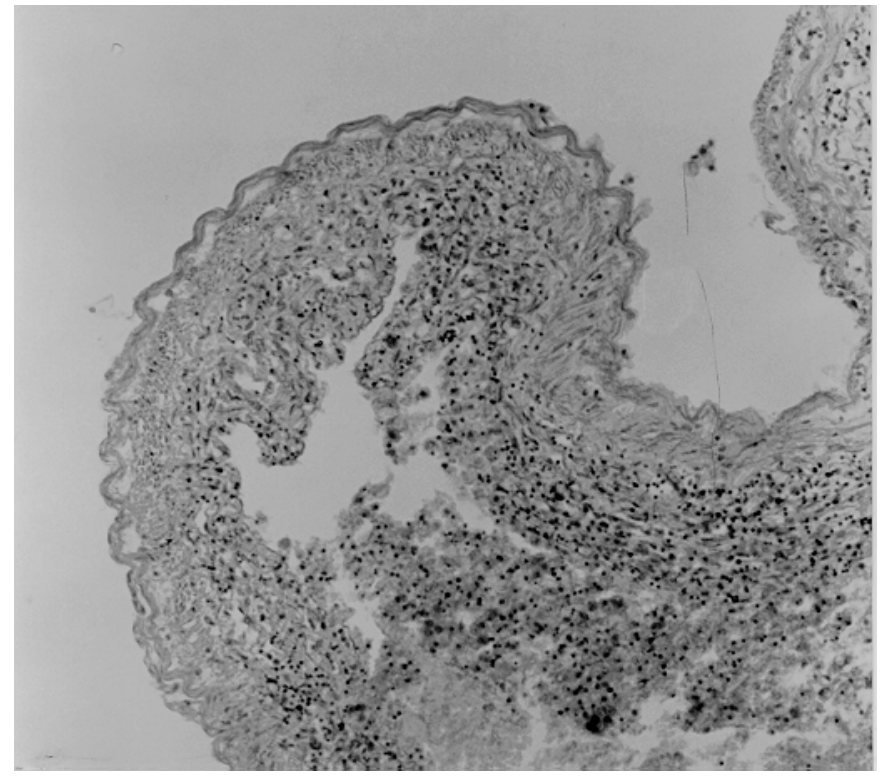

Fig. 7. Inflamed submucosa, necrotic and sloughed epithelium of the intestine. HE, $\times 90$

\section{Discussion}

The characteristics of the cytochrome oxidase negative isolates from carp in Group 1, presented in Table 2, correspond to those of $Y$. ruckeri. More detailed tests and serotyping were not carried out because the presence of a strain other than the inoculated one was not expected in septicaemia after intraperitoneal injection. The attributes of Pseudomonas sp. studied (Table 2) place it close to $P$. fluorescens.

Our results provide the first information on the pathogenicity of $Y$. ruckeri for the common carp under experimental conditions. The mortality rate of over $85 \%$ within 4 days with pathoanatomical and histological lesions characteristic of septicaemia as well as the reisolation of $Y$. ruckeri from internal organs of all experimental fish and its presence in pure culture in 14 out of 15 carp indicate the high susceptibility of this species to intraperitoneal infection with a relatively low dose. Comparison of our results with data reported by Stevenson et al. (1993) on virulence tests with serovar I and II strains for salmonids by intraperitoneal injection suggests a higher or equal sensitivity of experimental carp to this route of 
challenge. Two survivors on Day 28 had signs of chronic yersiniosis with prominent peritonitis, enteritis and anaemia. Factors of possible significance for the high susceptibility of experimental carp such as the temperature during the experiment, the physiological status including stress, as well as the relationship between fish size and dose of bacteria remain to be investigated.

The majority of septicaemic changes seen in the experimental carp were not very specific but still corresponded to those of ERM in salmonids (Rucker, 1966; Stevenson et al., 1993). However, enlargement and dark colour of the spleen (Rucker, 1966) were not found in carp. As in cases of Y. ruckeri infection in salmonids described by Frerichs et al. (1985) and Sparboe et al. (1986), most carp did not have reddened areas around the mouth. Findings corresponding to chronic proliferative peritonitis and to the depletion of haematopoietic kidney tissue in its major components in the two survivors sampled on Day 28 have not been reported so far. Peritonitis seems to be the consequence of long-lasting inflammation in the infected peritoneal cavity. From the peritoneal cavity the infection slightly progressed into organs (per continuitatem) as can be seen in Figs 3 and 6. The scarcity of erythroid, lymphoid and granuloid cells in the haematopoietic tissue should be viewed in the light of findings by Quentel and Aldrin (1986) and Lehmann et al. (1989) about decreased red and white blood cell counts in ERM-infected rainbow trout. Such blood cell loss was probably occurring in the two carp throughout the postinoculation period and could be responsible for the depletion of haematopoietic tissue seen 28 days after infection.

Our results raise the question whether carp yersiniosis can occur under natural circumstances. The hitherto reported incidence of $Y$. ruckeri in the intestine of healthy carp was low (Fuhrmann et al., 1984; Enriquez and Zamora, 1987) and the probability of a secondary infection thus seems to be remote. However, the relatively common and widespread occurrence of $Y$. ruckeri in the aquatic environment suggests that it may be involved in secondary septicaemic conditions in the same way as ubiquitous motile aeromonads (Roberts, 1993) and pseudomonads (Inglis and Hendrie, 1993).

\section{Acknowledgements}

The authors thank Dr. Nikola Fijan for support and help in this study. This research is part of a research supported by grants no. 3-03-284 and 053-073 of the Ministry of Science and Technology of the Republic of Croatia. 


\section{References}

Amos, K. H. (1985): Procedures for the Detection and Identification of Certain Fish Pathogens. $3^{\text {rd }}$ ed. Fish Health Section, American Fisheries Society, Corvallis, Oregon.

Austin, B. and Austin, D. A. (1987): Bacterial Fish Pathogens: Disease in Farmed and Wild Fish. Ellis Horwood Limited, Chichester.

Enriquez, R. and Zamora, J. (1987): Isolation of Yersinia ruckeri from carp (Cyprinus carpio) in Valdivia (in Spanish). Arch. Med. Vet. 19, 33-36.

Fijan, N., Sulimanovic, D., Bearzotti, M., Muzinic, D., Zwillenberg, L.O., Chilmonczyk, S., Vantherot, J. F. and de Kinkelin, P. (1983): Some properties of the epithelioma papulosum cyprini (E.P.C.) cell line from carp (Cyprinus carpio). Ann. Virol., Institut Pasteur 134E, 207-220.

Frerichs, G. N., Stewart, J. A. and Collins, R. O. (1985): Atypical infection of rainbow trout, Salmo gairdneri Richardson, with Yersinia ruckeri. J. Fish Dis. 8, 383-387.

Fuhrmann, H., Böhm, K. H. and Schlotfeldt, H.-J. (1984): On the importance of enteric bacteria in the bacteriology of freshwater fish. Bull. Eur. Ass. Fish Pathol. 4, 42-46.

Hugh, R. and Leifson, E. (1953): The taxonomic significance of fermentative versus oxidative metabolism of carbohydrates by various gram negative bacteria. J. Bacteriol. 66, 24-26.

Inglis, V. and Hendrie, M. S. (1993): Pseudomonadaceae. In: Inglis, V., Roberts, R. J. and Bromage, N. R. (eds) Bacterial Diseases of Fish. Blackwell Science Ltd, Oxford, pp. 167-174.

King, E. O., Ward, M. K. and Raney, D. E. (1954): Two simple media for the demonstration of pyocianin and fluorescein. J. Lab. Clin. Med. 44, 301-304.

Krieg, N. R. and Holt, J. G. (1984): Bergey's Manual of Systematic Bacteriology. Williams \& Wilkins, Baltimore.

Lehmann, J., Stürenberg, F. J. and Mock, D. (1989): Zum Blutbild aktiv vakzinierter und nicht vakzinierter Regenbogenforellen im Infektionsversuch mit dem Erreger der "Enteric Redmouth Disease" (ERM) In: Lillelund, K. and Rosenthal, H. (eds) Fish Health Protection Strategies. Bundesministerium für Forschung und Technologie (BMFT), Hamburg-Bonn, pp. 251-258.

McDaniel, D. V. (1971): Hagerman redmouth ... a new look at an old fish problem. Am. Fish U.S. Trout News 15 (5) 14-28; cit.: Bullock, G. L. and Snieszko, S. F. (1979): Enteric redmouth disease of salmonids. Fish Disease Leaflet 57, United States Department of the Interior Fish and Wildlife Service, Washington.

Oraić, D. (1993): Epizootiology and prophylaxis of yersiniosis in rainbow trout (Oncorhynchus mykiss) (in Croatian). Thesis, Zagreb.

Quentel, C. and Aldrin, J. F. (1986): Blood changes in catheterized rainbow trout (Salmo gairdneri) inoculated intraperitoneally with Yersinia ruckeri. Aquaculture 53, 169-185.

Romeis, B. (1968): Mikroskopische Technik. R. Oldenbourg Verlag, München-Wien.

Roberts, R. J. (1993): Motile aeromonad septicaemia. In: Inglis, V., Roberts, R. J. and Bromage, N. R. (eds) Bacterial Diseases of Fish. Blackwell Science Ltd, Oxford, pp. 143-155.

Ross, A. J., Rucker, R. R. and Ewing, W. H. (1966): Description of a bacterium associated with redmouth disease of rainbow trout (Salmo gairdneri). Can. J. Microbiol. 2, 763-770.

Rucker, R. R. (1966): Redmouth disease of rainbow trout (Salmo gairdneri). Bull. Off. Intern. Epiz. 65, 825-830.

Schlotfeldt, H.-J., Böhm, K. H., Pfortmüller, F. und Pfortmüller, K. (1985): "Rotmaulseuche"/ ERM (enteric redmouth disease) der Forelle und anderen Nutzfischen in Nordwestdeutschland - Vorkommen, Therapie und Vakzinierungsergebnisse. Tierärztl. Umschau 40, 985-995.

Sparboe, O., Koren, C., Hastein, T., Poppe, T. and Stenwig, H. (1986): The first isolation of Yersinia ruckeri from farmed Norwegian salmon. Bull. Eur. Ass. Fish Pathol. 6, 41-42. 
Stevenson, R., Flett, D. and Raymnod, B. T. (1993): Enteric redmouth (ERM) and other enterobacterial infections of fish. In: Inglis, V., Roberts, R. J. and Bromage, N. R. (eds) Bacterial Diseases of Fish. Blackwell Science Ltd, Oxford, pp. 80-105.

Thorsen, B. K., Enger, Oe., Norland, S. and Hoff, K. A. (1992): Long-term starvation survival of Yersinia ruckeri at different salinities studied by microscopical and flow cytometric methods. Appl. Environ. Microbiol. 58, 1624-1628.

Waltman, W. D. and Shotts, E. B. Jr. (1984): A medium for isolation of Yersinia ruckeri. Can. J. Fish. Aquat. Sci. 84, 804-806. 